DOI https://doi.org/10.30525/978-9934-26-000-1-2

\title{
ЖАНР ІНТЕРВ'Ю В ТЕАТРАЛЬНІЙ ПЕРІОДИЦІ УКРАЇНИ: ДИСКУРС, СТРАТЕГІЇ, ПРАКТИКИ
}

\author{
Галацька В. Л. \\ кандидат філологічних наук, \\ дочент кафедри теорії мистеитва \\ Дніпровський національний університет залізничного транспорту \\ імені академіка Всеволода Лазаряна \\ м. Дніпро, Украӥна
}

Сучасне театральне мистецтво України розвивається у глобалізованому соціумі як «мистецька медія». На думку швейцарського історика театру К. Бальме, воно набуває ознак перформансу і втілює мистецькі смисли національного синергетичного буття. Останнє розвивається в трьох ракурсах: нелінійності, нестабільності, несистемності.

Театральна комунікація породжує досить цікавий, асоціативно багатий, неповторний тип дискурсу, який позиціонується у сценічних діях акторів, режисерів, драматургів, а також у формі публіцистичної трансляції концептів сценічного буття. Жанр театрального інтерв'ю найадекватніше відображає сутність «запропонованих обставин» (за К. Станіславським), які є квінтесенцією акторської професії. На нашу думку, жанр театрального інтерв'ю, позиціонований сьогодні в спеціалізованих друкованих виданнях України «Кіно-театр», «Просценіум», «Театрально-концертний Київ», ефективно вибудовує комунікаційний ланцюг: комунікатор (журналіст) -комунікант (глядач, читач). Серед жанрових різновидів інтерв'ю в театрально-мистецькій площині виділяються такі різновиди: інтерв'ю-лейтмотивне, інтерв'ю- монолог, інтерв'ю біографічне, інтерв'ю-портрет.

Найбільш органічним у презентації театрального світу України виступає інтерв'ю-монолог, яке засвідчує драматизм світовідчуття героїв, їх внутрішню чесність, благородство натури. Так, наприклад, розмірковує заслужений артист України В.Жданов: «Чи розумніший став, чи мудріший, але нині я дістаю задоволення від того, що роблю...Це маленька місія, яка призводить до гармонії людини- зі світом, 3 ближніми» («Кіно-театр». - 2020. - № 4. - С. 23).

Театральне інтерв'ю можна визначити як мовну дію переважно інформаційного характеру, яка відбувається за специфічних умов і $€$ інструментом впливу на думки та дії аудиторії читачів. Цей жанровий різновид певною мірою залежний від мистецьких та соціокультурних позицій, світогляду учасників комунікативного процесу. 
Безпосередньо жанр інтерв'ю передбачає співпрацю всіх учасників комунікації. Сучасна українська журналістика має у своєму арсеналі систему правил спілкування щодо ведення інтерв'ю, у зв'язку 3 чим визначено три основні моделі комунікації: співробітництво, суперництво і конфронтація. Залежно від інтенцій (намірів) комунікантів ці моделі використовують у поєднанні всі учасники діалогу.

Процес спілкування у жанрі інтерв'ю передбачає взаємовплив учасників, відповідно він скерований на досягнення позитивної мети, ефективного спілкування. Відповідно жанр інтерв'ю є аргументативним різновидом публіцистичного дискурсу. Театральне інтерв'ю максимально позбавлене мовленнєвої агресії (за О. Фадєєвою), використовує нежорсткий спосіб мовленнєвого впливу (Г. Сагач).

Отже, театральний дискурс передбачає добровільність як основну характеристику мовленнєвого впливу: учасники комунікації надають потрібну інформацію, розділяють емоції за власним бажанням. При дослідженні текстів театрального інтерв'ю як частини суспільного медійного простору варто враховувати, що такий текст є комунікативним актом.

Діалог у жанрі театрального інтерв'ю складається 3 декількох структурних рівнів (зовнішнього і внутрішнього), до цього слід додати набір індивідуальних впливів, явні й приховані комунікативні наміри тощо. Саме тому варто звернутися до аналізу й виокремлення комунікативно значущих параметрів ситуації мовленнєвої взаємодії у жанрі театрального інтерв'ю.

Мовленнєва взаємодія відбувається за допомогою певного тактико-стратегічного комплексу, що формується під час мовленнєвої взаємодії. Це передбачає встановлення статусно-рольових позицій комунікантів, а значить, прийняття типів мовних особистостей співрозмовників, визначення рівня мовленнєвої активності учасників комунікативного процесу. Жанр інтерв'ю вважатимемо різновидом діалогічної взаємодії, де всі учасники інтерв'ю можуть брати активну участь у конструюванні дискурсу.

Театральне інтерв'ю дає можливість представити на сторінках періодичної преси спільну діяльність групи комунікантів, що визначили форму, структуру і зміст. Автори та учасники діалогу встановлюють часові та просторові обмеження висловлень, мовленнєвих ходів респондентів. Журналіст доповнює, підсумовує або корегує відповіді, регулює процес чергування реплік, також активно впливає на процеси топікального контролю.

За основу візьмемо типологію стратегій і тактик інтерв'юера (журналіста ) у жанрі театрального інтерв'ю (представлена таблиця). 


\begin{tabular}{|c|c|}
\hline Стратегї̈ & Тактики \\
\hline Епикетна страпесія & $\left.\begin{array}{ll}\text { - } & \text { презентація } \\
\text { - } & \text { відкриття } \\
\text { - } & \text { підтримування }\end{array}\right\} \begin{array}{r}\text { мовленнєвого } \\
\text { - } \\
\text { звершення }\end{array}$ \\
\hline $\begin{array}{c}\text { Стратеzія запиту } \\
\text { інформації }\end{array}$ & $\begin{array}{l}\text { - прямий запит інформації } \\
\text { - непрямий запит інформації }\end{array}$ \\
\hline $\begin{array}{l}\text { Стратехія корекції } \\
\text { наданої інформацї }\end{array}$ & $\left.\begin{array}{ll}- & \text { уточнення } \\
\text { - } & \text { конкретизація } \\
\text { - узагальнення }\end{array}\right\} \begin{array}{l}\text { інформації, } \\
\text { наданої } \\
\text { респондентом }\end{array}$ \\
\hline $\begin{array}{c}\text { Стратегія топікального } \\
\text { контролю }\end{array}$ & $\begin{array}{l}\text { - підтримування і розвиток теми; } \\
\text { - } \quad \text { зміна теми; } \\
\text { - відновлення попередньої теми. }\end{array}$ \\
\hline $\begin{array}{c}\text { Стратегія позитивнӧ̈ } \\
\text { самопрезентаціі }\end{array}$ & $\begin{array}{l}\text { - посилання; - натякання; - запобігання; } \\
\text { - симпатії; - компліментарність }\end{array}$ \\
\hline
\end{tabular}

Поняття «стратегія» у жанрі театрального інтерв'ю розуміємо як найбільш ефективну реалізацію інтенцій (намірів) мовця, що враховує особистісні (статусно-рольові й психологічні) характеристики співрозмовників. Ці наміри спрямовані на досягнення конкретної мети спілкування, продиктовані комунікативним досвідом. Усе це підпорядковує учасників інтерв'ю законам і нормам відповідної (у дослідженні театральної) сфери комунікації і змодельованої ситуації спілкування.

Слід зазначити, що система тактик жанру театрального інтерв’ю не обмежується вищезазначеними параметрами і є відкритою, постійно поновлюваною системою. Вона вибудовує цікаве дискурсивне обрамлення думки, програмуючи глибокий культурологічний контекст глобалізованої театральної епохи України. 